the Blashenwell tufa of Dorset, and other cases in which no precise dating is at present possible.

Is it altogether too late to return to this convenient arrangernent? Such a conservative course may not commend itself to those professional archrologists to whom even such a sesquipedalian invention as 'Epipalæolithic' has no terrors; but it would be a comfort to the general reader, and to those who, like myself, occasionally wander over the border between geology and archrology.

The Gate House,

Bournemouth West.

Henry Bury.

I AM grateful to my friend Mr. Harold Peake for dealing with this question of the term 'Mesolithic' so fully. Unfortunately, I am unable to doubt that this term has now received wide acceptance among archæologists. But this cannot alter the fact that from the point of view of a correct nomenclature it must be wrong to designate as 'mesolithic' specimens which are agreed on all sides to be referable to the latter part of the Stone Age. It is as if I were to be asked to acquiesce in calling 'mid-Victorian', circumstances, or objects, relating to the end of that epoch. I cannot believe that it is beyond the wit of archæologists to find some term, descriptive of the period and artefacts in question, which will not violate common-sense. Mr. Peake will perhaps allow me to express doubts as to whether I am the only archæologist who objects to the term 'mesolithic'. But, even if his dire prophecy is true, I am cheerfully prepared to remain in a minority of one in this matter.

One House Lane,

J. Raro Morr.

Ipswich.

Inheritance of Egg-Colour in the 'Parasitic' Cuckoos

Prof Punnetr ${ }^{1}$ has suggested that Prof. WynneEdwards' ingenious hypothesis ${ }^{2}$ for explaining how the gentes of 'parasitic' cuckoos may be kept distinct despite their promiscuous or polyandrous matinghabits could be replaced by the assumption that it is the $\boldsymbol{Y}$-chromosome of the mother which carries the factor assumed to determine the gens to which the offspring belong. It is not clear that such an alternative theory has any advantages over the original one (though it might have, were the degree of mimicry invariable). It seems slightly less plausible genetically owing to the paucity of known $\boldsymbol{Y}$-chromosome genes, and has the distinct disadvantage that it involves the offspring all belonging to the same gens as the mother; the "mechanism ... provided for stabilising the population by damping the fluctuations caused by the host species" which is inherent in Prof. WynneEdwards' theory is therefore lacking.

Both Prof. Wynne-Edwards and Prof. Punnett assume that the different gens factors postulated comprise a single series of multiple allelomorphs. The latter stresses this as an essential corollary, and considers as an objection to the hypothesis the fact that in the domestic hen egg-colour is determined by several independent autosomal genes. But the assumption of several pairs of sex-linked factors would explain the observations even better than a single multiple series, since it would account for the imperfection of mimicry found in areas where one species of cuckoo 'parasitises' several hosts. Further, Prof. Wynne-Edwards mentioned the probability that autosomal modifiers also exist. Prof. Punnett has cited one of many cases in which genes presumed to be phylogenetically homologous are situated on different chromosomes in different species. The assumption of a limited number of sex-linked pairs of genes rather than a single series would therefore seem to remove the only genetical objection raised by Prof. Punnett.

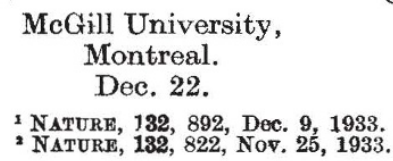

\section{Possible Chemical Nature of Tobacco Mosaic Virus}

DR. J. CALDWEL ${ }^{1}$ has criticised some of our statements on the possible chemical nature of the virus of tobacco mosaic. We must point out that the essential precipitant used in the Vinson and Petrie method is not basic lead acetate but neutral lead acetate. We are also quite aware of the fact that the addition of two volumes of acetone to one of aqueous $M / 1 \mathrm{KH}_{2} \mathrm{PO}_{4}$ solution produces a heavy precipitate of white rhombic crystals, but as Vinson and Petrie and ourselves were concerned with an M/15 solution of this salt, Caldwell's criticism is irrelevant. If acetone (two volumes) be added to an aqueous $M / 15$ solution of $\mathrm{KH}_{2} \mathrm{PO}_{4}$ or to an eleuate prepared from healthy sap, only a faint white opalescence makes its appearance and a slight precipitate settles after many hours.

It is mentioned in our communication that the crystalline fraction of the acetone precipitate is mainly composed of phosphate, but we still maintain that, although infective, it contains no nitrogen. The statement that the $N$. glutinosa method is a quantitative one for determination of virus is misleading, as at best the method can only give a very rough approximation of the relative concentration of the virus in samples of high dilution.

Scottish Society for Research

E. Barton-Wright.

Alan M. McBarn. in Plant Breeding,

Craigs House, Corstorphine, Edinburgh, 12. Feb. 6.

${ }^{1}$ NATURE, 138, 177, Feb. 3, 1934.

\section{A Tame Platypus}

WITH reference to the platypus mentioned in Nature of September 16, 1933, p. 446, Mr. R. Eadie, who has attended to the animal, informs me that it is still alive and has been, at the date of writing, in captivity for 282 days.

The references to diet require modification. The daily ration is at present 10 ounces of worms, 50 small tadpoles, wood grubs two or three times a week, and 2 eggs-usually duck eggs-every night. The eggs are prepared in the form of a batter and then steamed. When cold the mass is stirred with a fork until it consists of pieces the size of a large pea. Mr. Eadie estimates the quantity of food consumed at fourteen ounces daily. The weight of the platypus at the time of writing is three and a quarter pounds.

JAMES W. BARRETT.

\section{3-105 Collins Street,} Melbourne, C.1.

Nov. 21. 